Seminar Paper No. 221

A NEW LOOK AT ECONOMIC INTEGRATION

by

Wilfred Ethier

University of Pennsylvania

and

Henrik Horn*

This is a revised version of a paper prepared for the Conference on Monopolistic Competition in International Trade, Graduate Institute of International Studies, Geneva, June 21-23, 1982.

Seminar Papers are preliminary material circulated to stimulate discussion and critical comment.

October, 1982

Institute for International Economic Studies S-106 91 Stockholm Sweden 
This paper modifies the conventional analysis of customs unions by emphasizing four phenomena central to contemporary experience but less dealt with in the traditional literature: (i) product differentiation and intra-industry trade, scale economies and imperfect competition, (iii) changes in trade patterns stemming from elimination of tariffs on goods that are only traded within the union ("trade modification"), and (iv) sma11, rather than large, tariff changes. The paper derives two general propositions, employing (iii) and (iv), and discusses the implications for the optimal policy for countries considering integration. A special three-country general equilibrium model, incorporating all four features, is then employed to analyze how changes in internal and external tariffs affect product variety, terms of trade, trade flows, and welfare. It is shown that the implications for the three countries' welfare levels depend generally on the relation between the degree of product differentiation on the one hand, and properties of the economies' transformation functions on the other. The paper ends with an intermediate goods interpretation of the model. 


\section{A NEW LOOK AT ECONOMIC INTEGRATION}

The literature on customs unions theory is gargantuan. Nevertheless it strikes us as inadequate, both in the theoretical cases it addresses and in the actual circumstances of the world economy to which it is commonly thought relevant. This paper aims to spell out the details of this inadequacy and to indicate some ines along which the theory ought to be developed.

Section I very briefly describes basic ideas in contemporary customs union theory, and section 2 then discusses at some length necessary extensions. Two general propositions are advanced in the next section, and proved in section 4. Section 5 develops a specific model incorporating the new features, and section 6 then exhibits aspects of this model via some special comparative-statics exercises.

\section{Basics of Customs Union Theory}

There is a huge literature in this area for three distinct reasons: (i) the institutional fact that there are many types of discriminatory trade besides customs unions proper (preferential trading arrangements, free trade areas, common markets, economic unions, and so on), (ii) the subject demands disaggregation beyond two-country, two-commodity models, and therefore gives rise to many conceivable combinations of characteristics of countries, comodities, and trade flows, and (iii) the subject requires comparisons of distorted equilibria which, in particular in conjunction with the second point, increases the mathematical complexity of the analysis. In practice the latter two factors have proved decisive, with 
analysis concentrated disproportionately upon the case of a customs union proper (free internal trade combined with a common external tariff)。

Two basic ideas stand out from the wealth of specific analysis. The first, which might be called the Vinerian Description, is the notion that the net effect of a customs union is dependent on the balance of trade creation and trade diversion. This idea is in truth the very core of customs union theory:

(1) (Vinerian Description). Formation of a customs union produces trade creation between the partners, in response to the mutual elimination of tariffs on each other's goods, and trade diversion from third countries to the partners, in response to the tariff discrimination produced by the union.

Trade creation is by presumption beneficial and trade diversion harmful. Union formation is thus seen as a second-best exercise, with one distortion replaced by another. This, together with the need for at least some disaggregation, accounts for the multitude of separate possibilities. Other aspects of union formation have of course also received attention. Notable examples, to which we shall return, include changes in the terms of trade--both within the union and vis-a-vis the outside world--and also economies of scale and the degree of competition.

Mention of the terms of trade relative to the rest of the world brings us to the second basic idea, due to Kemp, Vanek, Ohyama and Wan. Setting the external tariffs at appropriate levels can cause the member countries, in the aggregate, to trade with the rest of the world exactly the same collection and quantities of 
goods that, in the aggregate, they traded prior to the union. Then the union will have no effect at all on the rest of the world, and the members must in the aggregate benefit, because the only effect they experience is the freeing of mutual trade. In essence, manipulation of the external tariff schedule allows any customs union to eliminate all trade diversion and so consist only of trade creation. By allowing a small deterioration in its external terms of trade, the union can ensure that also nonmembers benefit.

(2) (Kemp-Vanek-Ohyama-Wan). By an appropriate choice of common external tariffs and of lump-sum transfers among members, any customs union can assure that no countries in the world lose, and that some gain, as a result of

the formation of the union.

This proposition applies irrespective of initial conditions, and so establishes a sense in which the countries of the world always have incentives to form additional unions until global free trade is achieved.

\section{Desirable Departures}

Although the two ideas discussed above hardly begin to do justice to the vastness of customs union theory, they do indicate the distinguishing features of the subject and are its most important conclusions. Thus we take the pair as a benchmark from which to inquire in what direction contemporary problems mandate that the subject be further developed. We indicate four directions The four have by no means been completely ignored by the literature, and in some cases have received formal treatment, but they do depart substantially from the core of received customs unions theory • 
(a) Trade Modification. The basic element of the conventional theory is tariff discrimination: the same good that can be imported free of duty from a partner faces a tariff when it comes from a non-partner country. But partners also trade among themselves some goods which they do not import at all (either before or after the union) from outside countries. For want of a better term, we describe as trade modification the change in trade with outside countries due to the elimination of tariffs on goods traded only within the union. ${ }^{1}$ Thus trade modification differs from its familiar sister concept of trade diversion in that it can be produced by tariff changes consistent with the Most Favored Nation clause and with the GATT, that is, by economic integration resulting from the nondiscriminatory elimination by the partners of tariffs on goods they import only from each other.

Suppose, as an example, that France and Germany form a customs union, with France eliminating its tariff on German automotive supplies, also initially imported from America. This discriminatory tariff change would presumably induce trade diversion, with imports of German automotive supplies replacing some or all of the imports from America. Now suppose in contrast that France initially imports small cars from Germany and large cars from America, and that the integration takes the form of a French abolition of the tariff on small cars. Such a non-discriminatory tariff change is not usually considered as within the domain of customs union theory, even though it is likely to deflect French demand from American to German automotive products in about the same way as the previous case. Next, suppose instead that there is a unified world automobile irdustry, with France importing engines from Germany and bodies 
from America, and that France abolishes its tariff on engines. This again causes trade modification, but now French imports of American bodies will likely rise along with French imports of German engines. Trade modification differs from trade diversion in that it is not the result of geographical tariff discrimination but rather of the replacement of one set of tariffs by another, with the property that the tariffs which are changed apply directly to trade flows between a strict subset of countries. As the example makes clear, degrees of substitutability and complementarity between goods become crucial.

Extending the scope of the theory to encompass trade modification might well therefore open the gates to another flood of special cases-hardly welcome in this field especially. And the bulk of empirical work in the area cannot be interpreted as distinguishing trade diversion from trade modification. But there are good reasons why the theory should include both. First of course is that both are in principle part of the problem. More significant $i$ : he large volume of empirical work, by Kravis and Lipsey and many others, that in the last decade has revealed extensive international price discrimination at even quite disaggregated levels. As a result economists now tend, much more than before, to think of international trade as the exchange of differentiated products, rather than of homogeneous goods. This shift in perception calls for a shift in emphasis from trade diversion towards trade modification.

But the most important consideration is the range of phenomena to which the theory of economic integration ought to apply. Although many attempts at customs unions and free trade areas have been made since the Second World War, the only actual, substantially successful, instance 
to which the theory reflected in the Vinerian Description literally applies is western European integration. An important instance, to be sure, but past history. Customs union theory thus appears seldom to be used as a framework for thought about contemporary problems. But issues to which a theory of economic integration ought to apply are legion. As a glaring example, consider the dominant post-war exercise in global commercial policy: the cumulative tariff reductions produced by successive GATT rounds. As often emphasized by economists and men of affairs alike, these reductions have concentrated on trade in manufactures among the developed countries and have been much less relevant to the trade of LDCs. Thus we have experienced on an historical scale (and continue to do so as the Tokyo Round cuts are implemented) the very sort of nationally-biased tariff reductions that are the very essence of the theory of economic integration. But our theory has not been thought relevant because those cuts, implemented under the Most Favored Nation clause, directly conflict with the Vinerian Description. The incorporation of trade modification in addition to (or instead of) trade diversion is essential to the practical relevance of customs union theory. (b) Intra-Industry Trade and Product Differentiation. Related to the distinction between trade diversion and trade modification is the observation that customs union theory assumes trade in homogeneous products whereas product differentiation and intra-industry trade are pervasive in actual commerce. Theoretical models of these latter phenomena have been developed in recent years, and extension of these models to the theory of economic integration is obviously called for. Recall that our present widespread appreciation of the large and growing significance of intra-industry trade in the 
industrial world actually dates from studies of the effects of economic integration in Europe.

(c) Imperfect Competition and Scale Economies. These phenomena have been considered in the light of customs union theory in the past. What is clearly called for now is the application of recently developed general equilibrium approaches.

(d) "Small" Tariff Changes. Customs union theory has generally considered only "large" tariff changes between partners: the complete elimination of internal trade barriers. Exceptions ${ }^{2}$ have usually been accompanied by apologetic explanations of the convenience of marginal analysis. Large changes have been considered an essential aspect of the problem because theorists have often had in the backs of their minds the example of European integration, with free internal trade an objective from the start, and because the GATT rules permitting customs unions and free trade areas require the abolition of internal tariffs: mere reciprocal tariff preferences are ruled out. But a concern with contemporary problems should redirect attention toward small changes, rendering marginal analysis of interest in its own right. The successive GATT rounds have, at each stage, constituted an incremental change toward free trade among the developed countries. If translated into tariff equivalents, the numerous Voluntary Export Restraints of the "new protectionism" of recent years likewise constitute incremental changes, though in the direction of economic disintegration. Another potentially important example is furnished by the codes of conduct regarding nontariff barriers formulated during the Tokyo Round. These codes are not automatically binding on the GATT nations, or 
limited to them, but are to be individually acceded to by individual states. Thus each code seems likely to develop a circle of participating countries applying vis-à-vis each other the provisions of the code as regards the respective nontariff barrier, but applying more restrictive prior standards toward nonparticipating countries. Thus the codes might well produce non-tariff equivalents of preferential trading areas.

\section{Two Additional General Properties}

It is easier to undertake by stages the departures recommended in the previous section. We ignore for now imperfect competition and scale economies, but allow trade modification and inquire into the consequences of a small preferential change in tariffs, in a conventional context. Two general propositions, analogous to results well-known in the theory of trade and domestic distortions, follow easily once attention is directed toward small tariff changes.

Consider first an initial state of nondiscriminatory (but tariff-ridden) world trade. Suppose that some subset of countries then initiates a marginal mutual reduction of tariffs on trade with each other. (Since the role of the external terms of trade is understood, suppose for simplicity that no change takes place in the terms at which these countries deal with the rest of the world.) Since trade is initially nondiscriminatory, an additional unit of imports or exports by any country has the same effect on the welfare of residents of that country regardless of with whom the additional trade takes place. Thus the trade diversion and/or trade modification generated by the marginal preferential tariff reduction must 
have a zero first-order effect on welfare. But since trade is tariff ridden, an additional unit of imports will cost any country less than that unit's contribution to welfare: any trade creation must have a positive first-order effect.

(3) (Preferential Trade is Better than Free Trade). If tariffs are positive but nondiscriminatory, any subgroup of countries can raise its joint welfare by means of marginal preferential tariff reductions that increase the gross value of their total trade (in the specific sense that the new trade flows yield the partners more tariff revenue than the old flows, at the initial tariffs and prices), if the prices of goods exchanged between those countries and the rest of the world do not change.

This proposition differs from the Kemp-Vanek-Ohyama-Wan result in that it is limited to small tariff changes, whose relevance we have just advocated. What this limitation buys us is a dispensation from the need to adjust external tariffs so as to eliminate trade diversion and trade modification: their welfare effects will be swamped by those of trade creation.

Now consider the opposite initial situation: a group of countries, in a tariff-ridden world, have formed a customs union with free internal trade. Suppose these countries stage a "marginal retreat" from the union by imposing a small tariff on imports from each other. Free initial internal trade implies that a marginal import by any member from a partner yields a welfare increase equal to the welfare loss due to the exports required in payment. Thus the "trade destruction" caused 
by the marginal internal tariff will entail a zero first-order effect on welfare. But any increased trade with the rest of the world produces a positive first-order effect since the initial external tariffs imply that an additional import increases welfare by more than the sacrifice required to pay for it.

(4) (Preferential Trade is Better than a Customs Union). If any group of countries have free mutual trade in a tariff ridden world, their joint welfare will be increased by a marginal tariff on each other's goods that raises total trade with the rest of the world (in the specific sense that the new volume of trade yields the partners jointly more revenue than the old, at the original tariffs and prices), if the prices at which the partners trade with external countries do not change.

In essence, the net benefits from "undoing" some trade diversion and trade modification necessarily swamp the losses entailed by "trade destruction", for a small retreat from a customs union. This partially undercuts the consistent motives for union formation that seem to be supplied by idea (2). Also (3) and (4) together imply a motivation for tariff preferences that fall short of complete union. This is quite consistent with the prominent contemporary issues that the previous section argued ought to be addressable by the theory of economic integration.

4. A Formal Treatment

4.1. The mode1

This section supplies explicit proofs of propositions (3) and (4) and discusses them further. Assume three countries: two partners (A and B) and the rest of the world (distinguished by an 
asterisk). There is a total of $\mathrm{n}$ traded goods, divided into the twelve groups described in Table 1 . Groups 1 to 5 contain goods exported by country $A$, exportables are collected in groups 6-10, whereas country A doesn't trade goods in groups 11 and 12 .

(Table 1 here.)

For each group $i, Q_{i}$ denotes the n-vector with a zero in each component corresponding to a good not in group $i$, and with the country A domestic price of the respective good in each component that does so correspond. Thus $Q=\sum_{i=1}^{12} Q_{i}$ is the vector of country A domestic prices. Vectors $P_{i}$ apply analogously to the partner country, so $\mathrm{P}=\sum_{i=1}^{12} \mathrm{P}_{i}$ denotes the vector of country-B domestic prices.

In like fashion, $\mathrm{P}_{i}^{*}$ denotes the vector of prices actually paid to the rest of the world, or received from the rest of the world, for goods in group $i$ (with zeroes in components corresponding to other goods). Let $\mathrm{R}^{\mathrm{A}}=\mathrm{P}_{1}+\mathrm{P}_{2}^{*}+\mathrm{P}_{3}^{*}+\mathrm{P}_{4}^{*}+\mathrm{P}_{5}^{*}+\mathrm{Q}_{6}$ $+\mathrm{Q}_{7}+\mathrm{P}_{8}^{*}+\mathrm{P}_{9}^{*}+\mathrm{P}_{10}^{*}$. Then $\mathrm{R}_{\mathrm{A}}$ is the vector of prices at which country A actually transacts with foreigners, except possibly for those goods in group 5 that are imported from country $B$. In like manner, $\mathrm{R}^{\mathrm{B}}=\mathrm{P}_{1}+\mathrm{P}_{2}^{*}+\mathrm{P}_{4}^{*}+\mathrm{P}_{5}+\mathrm{Q}_{6}+\mathrm{P}_{7}^{*}+\mathrm{P}_{9}^{*}+\mathrm{P}_{10}^{*}$ $+\mathrm{P}_{11}^{*}+\mathrm{P}_{12}^{*}$ denotes $\mathrm{B}^{\prime} \mathrm{s}$ actual international transaction prices, except possibly for goods in group 7 imported from A.

$\mathrm{T}_{i}^{\mathrm{A}}$, for $\mathrm{i}=1, \ldots, 4$, is the $\mathrm{n} \mathrm{x} \mathrm{n}$ diagonal matrix with ad-valorem tariff rates of country $A$ on goods in group $i$ as the appropriate diagonal elements, and zeroes elsewhere. $\mathrm{T}_{5 \mathrm{~B}}^{\mathrm{A}}$ and $\mathrm{T}_{5 *}^{\mathrm{A}}$ likewise denote tariff matrices of country $\mathrm{A}$ on goods in group 5 imported from $B$ and from the rest of the world respectively. 
Country $\mathrm{B}$ tariff matrices $\mathrm{T}_{4}^{\mathrm{B}}, \mathrm{T}_{6}^{\mathrm{B}}, \mathrm{T}_{10}^{\mathrm{B}}, \mathrm{T}_{12}^{\mathrm{B}}, \mathrm{T}_{7 \mathrm{~A}}^{\mathrm{B}}$, and $\mathrm{T}_{7 *}^{\mathrm{B}}$ are defined analogous1y. Let $\mathrm{T}^{\mathrm{A}}=\mathrm{T}_{1}^{\mathrm{A}}+\mathrm{T}_{2}^{\mathrm{A}}+\mathrm{T}_{3}^{\mathrm{A}}+\mathrm{T}_{4}^{\mathrm{A}}+\mathrm{T}_{5 *}^{\mathrm{A}}$ and $\mathrm{T}^{\mathrm{B}}=\mathrm{T}_{4}^{\mathrm{B}}+\mathrm{T}_{6}^{\mathrm{B}}+\mathrm{T}_{7 *}^{\mathrm{B}}+\mathrm{T}_{10}^{\mathrm{B}}+\mathrm{T}_{12}^{\mathrm{B}}$. Then

$$
\begin{aligned}
& Q=\left(I+T^{A}\right) R^{A}, \\
& P=\left(I+T^{B}\right) R^{B} .
\end{aligned}
$$

Note also that $\left(I+T_{5 B}^{A}\right) P_{5}=\left(I+T_{5 *}^{A}\right) P_{5}^{*}$ and $\left(I+T_{7 A}^{B}\right) Q_{7}=\left(I+T_{7 *}^{B}\right) P_{7}^{*}$.

$M_{i}^{A}$ is the n-vector of country A net imports of goods in group $i$ (with zeroes elsewhere), and $M^{A}=\sum_{i=1}^{10} M_{i}^{A}$. Also $M_{5}^{A}=M_{5 B}^{A}+M_{5 *}^{A}$ and $\mathrm{M}_{10}^{\mathrm{A}}=\mathrm{M}_{10 \mathrm{~B}}^{\mathrm{A}}+\mathrm{M}_{10}^{\mathrm{A}}$ * where the two vectors on the right in each case record trade with country $B$ and the rest of the world respectively. Analogously for $M_{i}^{B}$, for $M^{B}=M_{1}^{B}+M_{2}^{B}+M_{4}^{B}+M_{5}^{B}+M_{6}^{B}+M_{7}^{B}+M_{9}^{B}+M_{10}^{B}+$ $M_{11}^{B}+M_{12}^{B}$, and for both $M_{2}^{B}=M_{2 A}^{B}+M_{2}^{B}$ and $M_{7}^{B}=M_{7 A}^{B}+M_{7 *}^{B}$. (Note that $\mathrm{M}_{1}^{\mathrm{A}}=-\mathrm{M}_{1}^{\mathrm{B}}, \mathrm{M}_{2}^{\mathrm{A}},=-\mathrm{M}_{2 \mathrm{~A}}^{\mathrm{B}}, \mathrm{M}_{5 \mathrm{~B}}^{\mathrm{A}}=-\mathrm{M}_{5}^{\mathrm{B}},-\mathrm{M}_{6}^{\mathrm{A}}=\mathrm{M}_{6}^{\mathrm{B}},-\mathrm{M}_{7}^{\mathrm{A}}=\mathrm{M}_{7 \mathrm{~A}}^{\mathrm{B}}$ and $-\mathrm{M}_{10 \mathrm{~B}}^{\mathrm{A}}=\mathrm{M}_{10}^{\mathrm{B}}$ ).

In country $A$, total expenditure -- denoted by the national expenditure function $e^{A}\left(Q, u_{A}\right)$, where $u_{A}$ denotes the vector of utilities of A residents -- must equal income, composed of tariff revenue plus the value of national production, the latter given by the national product function $y^{A}(Q)$. Thus

$$
\mathrm{e}^{\mathrm{A}}\left(\mathrm{Q}, \mathrm{u}_{\mathrm{A}}\right)=\mathrm{y}^{\mathrm{A}}(\mathrm{Q})+\mathrm{T}^{\mathrm{A}} \mathrm{R}^{\mathrm{A}}\left[\mathrm{M}^{\mathrm{A}}-\mathrm{M}_{5 \mathrm{~B}}^{\mathrm{A}}\right]+\mathrm{T}_{5 \mathrm{~B}}^{\mathrm{A}} \mathrm{P}_{5}^{\mathrm{A}} \mathrm{M}_{5 \mathrm{~B}}^{\mathrm{A}} \text {. }
$$

Analogously for the partner country:

$$
e^{B}\left(P, u_{B}\right)=y^{B}(P)+T^{B} R^{B}\left[M^{B}-M_{7 A}^{B}\right]+T_{7 A}^{B} Q_{7} M_{7 A}^{B} \text {. }
$$

\subsection{A basic expression}

Differentiating (1), noting that $\partial \mathrm{e}^{\mathrm{A}} / \partial \mathrm{Q}-\partial \mathrm{y}^{\mathrm{A}} / \partial \mathrm{Q}=\mathrm{M}^{\mathrm{A}}$ and that $d Q=d R^{A}+d\left(T^{A} R^{A}\right)$ gives

$$
\begin{aligned}
\frac{\partial e^{A}}{\partial u_{A}} d u_{A} & =-M^{A} d R^{A}-M_{5 B}^{A}\left[d\left(T^{A} R^{A}\right)-d\left(T_{5 B}^{A} P_{5}\right)\right]+T^{A} R^{A} d \bar{M}^{A}+ \\
& +T_{5 B}^{A} P_{5} d M_{5 B}^{A},
\end{aligned}
$$


where $\mathrm{M}^{\mathrm{A}} \equiv \mathrm{M}^{\mathrm{A}}-\mathrm{M}_{5 \mathrm{~B}}^{\mathrm{A}}$. In a like manner, we obtain for the partner country

$$
\begin{aligned}
\frac{\partial e^{B}}{\partial u_{B}} d u_{B} & =-M^{B} d R^{B}-M_{7 A}^{B}\left[d\left(T^{B} R^{B}\right)-d\left(T_{7 A}^{B} Q_{7}\right)\right]+T^{B} R^{B} d \bar{M}^{B}+ \\
& +T_{7 A}^{B} Q_{7} d M_{7 A^{\circ}}^{B}
\end{aligned}
$$

Equations (3) and (4) supply measures of the welfare effects on the partners of changes in commercial policy. The sources of these effects, spelled out on the right-hand sides of the equations, are analogous to the sources of welfare effects commonly discussed in conventional tariff theoryo ${ }^{3}$

We measure the change in the joint welfare of the partner countries by $d w=\frac{\partial e^{A}}{\partial u_{A}} d u_{A}+\frac{\partial e^{B}}{\partial u_{B}} \cdot d u_{B}$. Remember that we suppose constancy in the prices of which $A$ and $B$ transact with the rest of the world; implying

$$
M^{A} d R^{A}+M^{B} d R^{B}=-M_{5 B}^{A} d P_{5}-M_{7 A}^{B} d Q_{7} .
$$

With goods in group 5 (7) being bought from the rest of the world at prices assumed to be unchanged, $d\left(T^{A} R^{A}\right)\left(d\left(T^{B} R^{B}\right)\right)$ will have zero elements corresponding to positive entries in $\mathrm{M}_{5 \mathrm{~B}}^{\mathrm{A}}\left(\mathrm{M}_{7 \mathrm{~A}}^{\mathrm{B}}\right)$, and therefore

$$
\begin{aligned}
d W & =M_{5 B}^{A}\left[\mathrm{dP}_{5}+d\left(T_{5 B}^{A} P_{5}\right)\right]+T_{5 B}^{A} P_{5}\left(d M^{A}-d \bar{M}^{A}\right)+T^{A} R^{A} d \bar{M}^{A}+ \\
& +M_{7 A}^{B}\left[d_{7}+d\left(T_{7 A}^{B} Q_{7}\right)\right]+T_{7 A}^{B} Q_{7}\left(d M^{B}-d \bar{M}^{B}\right)+T^{B} R^{B} d \bar{M}^{B}
\end{aligned}
$$

where $T_{5 B}^{A} P_{5}\left(T_{7 A}^{B} Q_{7}\right)$ has zeroes corresponding to non-zero elements of $\mathrm{d}^{\mathrm{A}}{ }^{\mathrm{A}}\left(\mathrm{d} \overline{\mathrm{M}}^{\mathrm{B}}\right)$. Furthermore,

$$
\begin{aligned}
& \mathrm{dP}_{5}+\mathrm{d}\left(\mathrm{T}_{5 \mathrm{~B}}^{\mathrm{A}} \mathrm{P}_{5}\right)=\mathrm{d}\left[\left(\mathrm{I}+\mathrm{T}_{5 \mathrm{~B}}^{\mathrm{A}}\right) \mathrm{P}_{5}\right]=\mathrm{d}\left[\left(\mathrm{I}+\mathrm{T}_{5 *}^{\mathrm{A}}\right) \mathrm{P}_{5}^{*}\right]=\mathrm{P}_{5}^{*} \mathrm{dT}_{5 *}^{\mathrm{A}} \\
& \mathrm{dQ}_{7}+\mathrm{d}\left(\mathrm{T}_{7 \mathrm{~A}}^{\mathrm{B}} \mathrm{Q}_{7}\right)=\mathrm{d}\left[\left(\mathrm{I}+\mathrm{T}_{7 \mathrm{~A}}^{\mathrm{B}}\right) \mathrm{Q}_{7}\right]=\mathrm{d}\left[\left(\mathrm{I}+\mathrm{T}_{7 *}^{\mathrm{B}}\right) \mathrm{P}_{7}^{*}\right]=\mathrm{P}_{7}^{*} \mathrm{dT}_{7 *}^{\mathrm{B}}
\end{aligned}
$$


Since also $M_{5 B}^{A}\left(M_{7 A}^{B}\right)$ has zero elements corresponding to non-zero elements in $\mathrm{P}_{5}^{*} \mathrm{dT}_{5 *}^{\mathrm{A}}\left(\mathrm{P}_{7}^{*} \mathrm{dT}_{7 *}^{\mathrm{B}}\right)$, our expression for the effect of tariff changes on the partners' joint welfare simplifies to

$$
d W=\left(T_{5 B^{A}}^{A} P_{5}\right) d M^{A}+\left(T_{7 A^{B}}^{B} Q_{7} d^{B}+\left(T^{A} R^{A}\right) \cdot d \bar{M}^{A}+\left(T^{B} R^{B}\right) d \bar{M}^{B} .\right.
$$

This is our basic result. We now apply it to two special cases in order to derive propositions (3) and (4).

\subsection{The propositions}

Suppose first that all tariffs are initially nondiscriminatory, so that $\mathrm{T}_{5 . \mathrm{B}}^{\mathrm{A}}=\mathrm{T}_{5^{*}}^{\mathrm{A}}, \mathrm{P}_{5}=\mathrm{P}_{5}^{*}, \mathrm{~T}_{7 \mathrm{~A}}^{\mathrm{B}}=\mathrm{T}_{7 *}^{\mathrm{B}}$, and $\mathrm{Q}_{7}=\mathrm{P}_{7}^{*}$. Equation (6) then reduces to

$$
d W=\left(T^{A} R^{A}\right) d M^{A}+\left(T^{B} R^{B}\right) d M^{B} .
$$

Thus a small discriminatory tariff change (or any other small change) raises joint welfare if and only if the changes in trade volume would increase joint tariff revenues at the initial rates and prices, as was stated in proposition (3) above. Note in particular two aspects of this result.

First, the degree of trade diversion -- reflected in the composition of $\mathrm{dM}_{5}^{\mathrm{A}}$ between $\mathrm{dM}_{5 \mathrm{~B}}^{\mathrm{A}}$ and $\mathrm{dM}_{5 *}^{\mathrm{A}}$ and in the composition of $\mathrm{dM}_{7}^{\mathrm{B}}$ between $\mathrm{dM}_{7 \mathrm{~A}}^{\mathrm{B}}$ and $\mathrm{dM}_{7 *^{--}}^{\mathrm{B}}$ has no influence at a11 on $\mathrm{dW}$. This is to be expected in the light of the previous section's informal discussion.

Second, trade modification -- reflected in the magnitudes of $\mathrm{dm}_{3}^{\mathrm{A}}, \mathrm{dM}_{4}^{\mathrm{A}}, \mathrm{dM}_{4}^{\mathrm{B}}$, and $\mathrm{dM}_{12}^{\mathrm{B}}$-- will add to or subtract from $\mathrm{dW}$ according as the goods involved are in this sense complementary to or substitutes for intra-union trade. This, again, is not surprising in view of the earlier discussion. Indeed, if the goods which 
countries $A$ and $B$ trade exclusively with the rest of the world are sufficiently strong substitutes for the goods they exchange with each other, they could have an incentive to form an "anti-union", that is, to add a marginal discriminatory tariff on each others' goods. The two would have reason to seek separate preferential arrangements with the rest of the world, rather than with each other.

Suppose next that $A$ and $B$ initially have a full free-trade area and impose marginal internal tariffs. Then $\mathrm{T}_{1}^{\mathrm{A}}=\mathrm{T}_{2}^{\mathrm{A}}=\mathrm{T}_{5 \mathrm{~B}}^{\mathrm{A}}=$ $\mathrm{T}_{6}^{\mathrm{B}}=\mathrm{T}_{7 \mathrm{~A}}^{\mathrm{B}}=\mathrm{T}_{10}^{\mathrm{B}}=0$ and (6) reduces to $d W=\left(T^{A} R^{A}\right) d \bar{M}^{A}+\left(T^{B} R^{B}\right) d \bar{M}^{B}$

Thus a marginal retreat from internal free trade will raise the partners' joint welfare if and only if it raises total tariff revenue collected on trade with the rest of the world, as stated above in proposition (4). It is instructive to decompose the right-head side of (8) as follows:

$$
\begin{aligned}
\mathrm{dW} & =\left(\mathrm{T}_{5 *}^{\mathrm{A}} \mathrm{P}_{5}^{*} \mathrm{dM}_{5 *}^{\mathrm{A}}+\mathrm{T}_{7 *}^{\mathrm{B}} \mathrm{P}_{7}^{*} \mathrm{dM}_{7 *}^{\mathrm{B}}\right)+\left(\mathrm{T}_{3}^{\mathrm{A}} \mathrm{P}_{3}^{*} \mathrm{dM}_{3}^{\mathrm{A}}+\mathrm{T}_{4}^{\mathrm{A}} \mathrm{P}_{4}^{*} \mathrm{dM}_{4}^{\mathrm{A}}+\mathrm{T}_{4}^{\mathrm{B}} \mathrm{P}_{4}^{*} \mathrm{dM}_{4}^{\mathrm{B}}+\right. \\
& \left.+\mathrm{T}_{12}^{\mathrm{B}} \mathrm{P}_{12}^{*} \mathrm{dM}_{12}^{\mathrm{B}}\right)
\end{aligned}
$$

Note that an "undoing" of trade diversion -- indicated by positive terms within the first set of parentheses on the right-hand side of (9) -- must increase $W$ regardless of how great the accompanying reduction in intra-union trade in the same goods happens to be. This is a consequence of the initial free internal trade, as discussed in the previous section.

The influence of trade modification is summarized by the second parenthesized term on the right-hand side of (9). Joint partner welfare is thereby raised or lowered according as this term is positive or 
negative, that is, according as the goods traded exclusively with the rest of the world are in this sense on balance substitutes for or complementary to intra-partner trade.

Trade diversion and trade modification are central in both exercises. The presumptive role of trade diversion is clear: it should cause both a marginal reduction of a discriminatory tariff and a marginal retreat from a free-trade area to raise joint partner welfare. But the role of trade modification depends crucially upon whether the goods traded exclusively with the rest of the world are on balance substitutes for or complements to intraunion trade, in the sense that discrimination in favor of the latter reduces or increases the volume of the former, with the change in this volume measured by the net change in partner tariff revenue it would generate at initial prices and tariffs.

Neither nondiscrimination nor a free trade area would constitute an optimal policy -- for A and B jointly, given tariffs on goods from the rest of the world -- without a very special balancing of the various influences discussed above. If exclusively external trade is on balance neither strongly substitutable for nor complementary to internal trade, optimal policy for the partners will presumably entail tariff preferences that fall short of a full free trade area, so that both non-discrimination and customs unions should be unstable.

Significant net substitutability both reduces the gain from initial preferences and increases the gain to a retreat from a full union. Thus one expects it to cause optimal policy to feature a lower degree of preference. Sufficient substitutability should make optimal an "anti union" with the members actually discriminating against each 
other. Significant net complementarity, finally, increasing the gain from initial preferences and reducing that from a retreat, presumably cause the optimal policy to more closely approximate free internal trade. Large enough complementarity could cause the optimal policy to be a "super union" with internal trade actually stimulated by subsidies financed by tariffs on external trade. Note that the European Community's Common Agricultural Policy -- which does not naturally come to mind in a discussion of optimality -- does in fact possess some of the characteristics of such a case.

5. Scale Economies and Product Differentiation: A Special Model

The previous sections focused on trade modification as well as trade-diversion and considered small tariff changes rather than large ones. But we said nothing about induced change in the number of distinct commodities (that is, in the degree of product differentiation), and, more prominently yet, imperfect competition and scale economies are foreign to the optimality conditions central to the logic of the propositions. Thus we have set off on some but not all of those departures from standard theory that we have argued for.

We have no wish to construct the awesome structure that would simply add our further suggested infovations to what we have already done in the previous section. Instead we now consider a special model that incorporates our four desired departures in as sharp a fashion as possible: by abstracting from other features. For better or worse, this is also the strategy used in the recent literature on international trade and scale economies, imperfect competition, and product differentiation.

We continue to suppose three countries: the partners ( $A$ and $B$ ) and the rest of the world, denoted by an asterisk. A and $B$ can be 
thought of as DCs, the rest of the world as an LDC. A and B produce goods in two common sectors: manufactures and food. There are $\mathrm{n}$ and $m$ different variants of manufactures produced in $A$ and $B$, respectively. They are all (equally) imperfect substitutes to each other from the consumer's point of view, although they are produced with the same homothetic technology, characterized by internal, increasing returns to scale. Food, on the other hand, is produced in all three countries, under constant returns to scale.

We consider the following special trade pattern. A and B export their respective manufactures to each other and to the rest of the world, and both countries import food from the latter. We assume furthermore that $A$ and $B$ have formed a customs union with their in internal tariff $\tau$ set at zero, and with a common external tariff $t$. The rest of the world imposes no trade restrictions.

It is clear that, with such a trade pattern, this customs union does not cause any trade diversion, since the nonmember country exports a different good than the union countries do. But the union will give rise to trade creation and trade modification.

Following, e.g., Dixit and Stiglitz (1977), we assume the preferences of each country's representative consumer to be given by

$$
U^{k}=\left(\sum_{i=1}^{n}\left(X_{i}^{k}\right)^{\beta}+\sum_{j=1}^{m}\left(Y_{j}^{k}\right)^{\beta}\right)^{\frac{\alpha}{\beta}}\left(z^{k}\right)^{1-\alpha} ; k=A, B, *
$$

with $0<\alpha<1$, and $0<\beta<1$, and where $x_{i}^{k}$ is the amount of the country A-produced manufacture $i$ that is consumed in country $k, Y_{j}^{k}$ is the amount of the country B-produced manufacture $j$ that is consumed in $k$, and $\mathrm{z}^{\mathrm{k}}$ the consumed quantity of food in $\mathrm{k}$.

The equilibrium under study is characterized by strong symmetry, in the sense that $X_{i}^{k}=X^{k}, \forall_{i}$, and $Y_{j}^{k}=Y^{k}, \forall_{j}$. When this is taken 
into account, (10) gives the following demand functions

$$
\begin{aligned}
& \mathrm{PX}^{\mathrm{A}}=\frac{\alpha \mathrm{I}^{\mathrm{A}}}{\mathrm{n}+\mathrm{m} \mathrm{y}_{\mathrm{A}}^{\mathrm{B}}} \quad \text { where } \mathrm{y}_{\mathrm{A}} \equiv \frac{\mathrm{Y}^{\mathrm{A}}}{\mathrm{X}^{\mathrm{A}}} \\
& Q(1+\tau) Y^{A}=\frac{\alpha I^{A}}{\mathrm{ny}_{\mathrm{A}}^{-\beta}+\mathrm{m}} \\
& P_{F}(1+t) Z^{A}=(1-\alpha) I^{A} \\
& P(1+\tau) X^{B}=\frac{a I^{B}}{n+m y_{B}^{\beta}}
\end{aligned}
$$

$$
\begin{aligned}
& Q Y^{B}=\frac{\alpha I^{B}}{n y_{B}^{-\beta}+m} \\
& P_{F}(1+t) Z^{B}=(1-\alpha) I^{B}
\end{aligned}
$$$$
\mathrm{P} \mathrm{X}^{*}=\frac{\alpha \mathrm{I}^{*}}{\mathrm{n}+\mathrm{my}_{*}^{\beta}}
$$$$
\mathrm{Q} \mathrm{Y}^{*}=\frac{\alpha \mathrm{I}^{*}}{\mathrm{ny}_{*}^{-\beta}+\mathrm{m}}
$$

$$
P_{F} Z^{*}=(1-\alpha) I^{*}
$$

where $P$ and $Q$ are the prices received by producers of manufactured products in $A$ and $B$, respectively; $P_{F}$ is the price of food excluding the tariff; $\tau$ and $t$ are the internal and the external tariffs, respectively; and $\mathrm{I}^{\mathrm{k}}$ is the consumers ${ }^{\prime}$ income in country $\mathrm{k}$.

Let us now turn to the production side. The production process formanufactures can be thought of as consisting of two stages: first 
primary factors are used to produce a (non-traded) intermediate input under constant returns to scale, in the amounts $\mathrm{M}^{\mathrm{A}}$ and $\mathrm{M}^{\mathrm{B}}$ in the two DCs. This input is transformed to final differentiated goods under increasing returns. This implies that each firm in the manufacturing sector in $A$ employs $\mathrm{M}^{\mathrm{A}} / \mathrm{n}$ of the intermediate good, and corresponding $1 \mathrm{y} \mathrm{M}^{\mathrm{B}} / \mathrm{m}$ in $\mathrm{B}$. We assume that entry is free, so the condition for industry equilibrium is that profits are zero

$$
P X=r^{A} \frac{M^{A}}{n} \text {, and } Q Y=r^{B} \frac{M^{B}}{m}, \quad(11 a, b)
$$

where $r$ is the price of the intermediate input, and where $X \equiv X^{A}+X^{B}+X^{*}$, and $Y \equiv Y^{A}+Y^{B}+Y^{*}$. The internal increasing returns to scale stem from a fixed cost a, coupled with a constant marginal cost $\mathrm{b}$. We could therefore alternatively simply define

$$
M^{A} \equiv n(a+b X) \text {, and } M^{B} \equiv m(a+b Y) \text {, }
$$

and consider $r^{A}$, and $r^{B}$, as the "factor-price index" in the separable cost function.

The conditions for profit maximization in the two manufacturing industries can be stated as

$$
\mathrm{P} \beta=\mathrm{r}^{\mathrm{A}} \mathrm{b} \text {, and } \mathrm{QB}=\mathrm{r}^{\mathrm{B}} \mathrm{b} . \quad(12 \mathrm{a}, \mathrm{b})
$$

To express the conditions in this form we use the fact that each firm will adjust its quantities in the three markets in such a way that it receives the same price everywhere.

Now, from (11) and (12) we immediately get that the total output volume of a firm in the manufacturing sectors is fixed

$$
X=Y=\frac{a}{b} \frac{\beta}{1-\beta} .
$$


This is in particular due to the homothetic technology. It then follows that

$$
\mathrm{n}=\frac{1-\beta}{\alpha} \mathrm{M}^{\mathrm{A}} \text {, and } \mathrm{m}=\frac{1-\beta}{\alpha} \mathrm{M}^{\mathrm{B}} \text {. }
$$

The union countries' respective output of food is given by the transformation functions $\mathrm{T}\left(\mathrm{M}^{\mathrm{A}}\right)$ for $\mathrm{A}$, and $\mathrm{S}\left(\mathrm{M}^{\mathrm{B}}\right)$ for $\mathrm{B}$. The domestic produce is sold at the same price as imported food: $P_{F}(1+t)$. The price of the intermediate good must be the value of the alternative use of the resources devoted to the production of one unit of the good, or

$$
\begin{aligned}
& r^{A}=-P_{F}(1+t) T^{\prime}\left(M^{A}\right), \\
& r^{B}=-P_{F}(1+t) S^{\prime}\left(M^{B}\right)
\end{aligned}
$$

The rest of the world is assumed to use one factor only, with the reward $\mathrm{r}^{*}$, and with the fixed supply $\mathrm{L}^{*}$. It takes one unit of this factor to produce one unit of food, and the condition for profit maximization (and industry equilibrium) is therefore simply

$$
\mathrm{P}_{\mathrm{F}}=\mathrm{r}^{*}
$$

Two variables that will be of interest in the comparative statics exercises are the internal and external terms-of-trade, $q \equiv \frac{Q}{P}$, and $p \equiv \frac{P F}{P}$, respectively. With the aid of (11) and (13), and recalling the definitions of $\mathrm{M}^{\mathrm{A}}$ and $\mathrm{M}^{\mathrm{B}}$, the two variables may be expressed as

$$
\begin{aligned}
& q=\frac{S^{\prime}\left(M^{B}\right)}{T^{\prime}\left(i N^{A}\right)}, \\
& p=\frac{-\beta}{b P_{F}(1+t) T^{\prime}\left(M^{A}\right)} .
\end{aligned}
$$


Let us finally, before proceeding to the comparative statics exercises, give the clearing conditions for the goods markets

$$
\begin{aligned}
& X=\frac{\alpha}{P}\left[\frac{I^{A}}{n+m_{A}^{\beta}}+\frac{I^{B} /(1+\tau)}{n+m y_{B}^{\beta}}+\frac{I^{*}}{n+m y_{*}^{\beta}}\right] \\
& Y=\frac{\alpha}{Q}\left[\frac{I^{A} /(1+\tau)}{n y_{A}^{-\beta}+m}+\frac{I^{B}}{n y_{B}^{-\beta}+m}+\frac{I^{*}}{n y_{*}^{-\beta}+m}\right], \\
& L^{*}+T\left(M^{A}\right)+S\left(M^{B}\right)=\frac{(1-\alpha)}{P_{F}}\left[I^{A} /(1+t)+I^{B} /(1+t)+I^{*}\right]
\end{aligned}
$$

Comparative statics exercises will be conducted to expose the basic nature of our model. To have a recognizable point of departure and standard of comparison, we shall conduct an exercise similar to that of proposition (4) discussed in sections 3 and 4. Thus we start with internal free trade $(\tau=0)$, and with a common positive external tariff $(t>0)$. We first increase the common external tariff and than increase the common internal tariff. Our method is to differentiate the system and to reduce it to two equations, giving combinations of (the relative change in) $n$ and $m$ consistent with market clearing. In doing this we also derive some expressions of interest in their own right. To facilitate matters we make the following assumption: the partners have a transfer scheme such that the relative changes in their incomes are identical and equal to $\hat{I}$. This reflects our concern with the partners' joint experience, but is not without practical relevance: the Common Market is an example of a union with an internal transfer scheme. Since we use $P_{F}$ as the numeraire, we have from (18): 


$$
\hat{I}=-\frac{P n X}{I^{A}+I^{B}} \hat{M}^{A}-\frac{Q m Y}{I^{A}+I^{B}} \hat{M}^{B}+\hat{t}
$$

where $\hat{t} \equiv \frac{d t}{1+t}$.

The numbers of firms in the manufacturing sectors are proportional to the output of the two intermediate goods

$$
\begin{aligned}
& \hat{\mathrm{n}}=\hat{\mathrm{M}}^{\mathrm{A}}, \\
& \hat{\mathrm{m}}=\hat{\mathrm{M}}^{\mathrm{B}} .
\end{aligned}
$$

The terms-of-trade changes are directly obtained from (14) and (15)

$$
\begin{aligned}
& \hat{\mathrm{q}}=\sigma \hat{\mathrm{B}}-\sigma \hat{\mathrm{n}} \\
& \hat{p}=-\hat{t}-\sigma \hat{n}, \\
& \text { where } \sigma^{A} \equiv \frac{M^{A} T^{\prime \prime}\left(M^{A}\right)}{T^{\prime}\left(M^{A}\right)} \text {, and } \sigma^{B} \equiv \frac{M^{B} T^{\prime \prime}\left(M^{B}\right)}{T^{\prime}\left(M^{B}\right)} \text {. } \\
& \hat{\mathrm{y}}_{\mathrm{A}}=\left(\sigma^{\mathrm{B}} \hat{\mathrm{m}}-\sigma \hat{\mathrm{A}}+\hat{\tau}\right) \gamma(B-1) \\
& \hat{y}_{B}=\left(\sigma^{B} \hat{m}-\sigma \hat{n}-\hat{\tau}\right) /(B-1) \\
& \hat{y}_{*}=(\sigma \hat{m}-\sigma \hat{n}) /(B-1) \\
& \hat{z}_{A}=\hat{n}+\frac{m}{n+m}\left(\frac{\beta}{1-\beta} \sigma^{A}-1\right)(\hat{n}-\hat{m})-\frac{m}{(n+m)}\left(\frac{\beta}{1-\beta}\right) \hat{\tau}, \\
& \hat{z}_{B}=\hat{n}+\frac{m}{n+m}\left(\frac{\beta}{1-\beta} \sigma^{A}-1\right)(\hat{n}-\hat{m})+\left(1+\frac{m}{n+m} \frac{\beta}{1-\beta}\right) \hat{\tau}, \\
& \hat{z}_{*}=\hat{n}+\frac{m}{n+m}\left(\frac{\beta}{1-\beta} \sigma^{A}-1\right)(\hat{n}-\hat{m}),
\end{aligned}
$$


where $\hat{\tau} \equiv \mathrm{d} \tau /(1+\tau)$, and $z_{k} \equiv \mathrm{z}^{\mathrm{k}} / \mathrm{X}^{\mathrm{k}}$ for $\mathrm{k}=\mathrm{A}, \mathrm{B}, *$.

The following two expressions are reduced forms of the market equilibrium conditions for X- and Y-goods, respectively, and they will be the starting point of the proceeding analysis:

$$
\begin{aligned}
-\theta * \hat{t}- & {\left[\theta^{B}+\left(\theta^{B}-\theta^{A}\right) \frac{\beta}{(1-\beta)} \frac{m}{(n+m)}\right] \hat{\tau}=\left[\sigma^{A}+1+\theta^{B} \alpha-\right.} \\
& \left.-\left(\theta^{B}-\theta^{A}\right) \alpha \frac{n}{n+m}\right] \hat{n}+\frac{m}{n+m}\left[\frac{\beta}{1-\beta} \sigma^{A}-1-\theta^{B} \alpha\right](\hat{n}-\hat{m})+ \\
& +\frac{m}{(n+m)}\left(\frac{\beta}{1-\beta}\right)\left(\sigma^{A}-\sigma^{B}\right) \hat{m} \\
-\theta * \hat{t}- & {\left[\theta^{A}-\left(\theta^{B}-\theta^{A}\right) \frac{\beta}{(1-\beta)} \frac{n}{(n+m)}\right] \hat{\tau}=\left[\sigma^{B}+1+\theta^{A}+\right.} \\
& \left.+\left(\theta^{B}-\theta^{A}\right) \alpha \frac{m}{n+m}\right] \hat{m}-\frac{n}{n+m}\left[\frac{\beta}{1-\beta} \sigma^{B}-1-\theta^{A} \alpha\right](\hat{n}-\hat{m})- \\
& -\frac{n}{(n+m)} \frac{\beta}{(1-\beta)}\left(\sigma^{A}-\sigma^{B}\right) \hat{n}
\end{aligned}
$$

where $\theta^{k}$ is the share of world income for country $k$.

We subsequently make the special assumption that $\sigma^{A}=\sigma^{B} \equiv \sigma$, i.e., that the elasticities of the slopes of the transformation curves are the same at the equilibrium point, in the two union countries. This has the merit, aside from increased analytical tractability, of highlighting aspects of particular interest: the importance of the degree of product differentiation and the importance of asymmetries between the member countries in the relative sizes of their manufacturing sectors and also in their relative incomes.

(28) and (29) give the following solution for relative changes in the number of variants produced in the menber countries: 


$$
\begin{aligned}
& \hat{\mathrm{n}}=-\frac{\theta^{*}}{\Delta} \hat{\mathrm{t}}-\left[\theta^{\mathrm{B}}+\left(\theta^{\mathrm{B}}-\theta^{\mathrm{A}}\right) \frac{\left(1+\alpha \theta^{\mathrm{B}}\right)}{\sigma} \frac{\mathrm{m}}{(\mathrm{n}+\mathrm{m})}\right] \frac{1}{\Delta} \hat{\tau}, \\
& \hat{\mathrm{m}}=-\frac{\theta^{*}}{\Delta} \hat{\mathrm{t}}-\left[\theta^{\mathrm{A}}-\left(\theta^{\mathrm{B}}-\theta^{\mathrm{A}}\right) \frac{\left(1+\alpha \theta^{\mathrm{A}}\right)}{\sigma} \frac{\mathrm{n}}{(\mathrm{n}+\mathrm{m})}\right] \frac{1}{\Delta} \hat{\tau}, \\
& \hat{\mathrm{n}}-\hat{\mathrm{m}}=\frac{\left(\theta^{\mathrm{A}}-\theta^{\mathrm{B}}\right)}{\sigma} \hat{\tau}, \\
& \text { and } \hat{\mathrm{N}}=-\frac{\theta^{*}}{\Delta} \mathrm{t}-\frac{\Gamma}{\Delta} \hat{\tau},
\end{aligned}
$$

where $\mathrm{N} \equiv \mathrm{n}+\mathrm{m}$,

$$
\Delta \equiv 1+\sigma+\alpha\left(\theta^{A} \frac{n}{n+m}+\theta^{B} \frac{m}{n+m}\right)>0,
$$

and $\quad \Gamma \equiv \theta^{A} \frac{m}{n+m}+\theta^{B} \frac{n}{n+m}+\left(\theta^{B}-\theta^{A}\right)^{2} \frac{\alpha}{\sigma} \frac{n m}{(n+m)^{2}}>0$.

We will below also analyze welfare implications of tariff changes. To facilitate the understanding of the results we end this section with a preliminary description of ways in which tariff changes may affect welfare. It is for this task convenient to reformulate the utility function (10) by using its indirect form. The indirect utility functions differ between countries due to differences in the tariff structures facing consumers. To save space we concentrate on country $A$ and the rest of the world. The indirect utility function for country $\mathrm{A}$ is

$$
\mathrm{V}^{\mathrm{A}}=\mathrm{A}\left(\mathrm{R}^{\mathrm{A}}\right)^{-\alpha}(1+t)^{-(1-\alpha)} \mathrm{I}^{\mathrm{A}} \text {, }
$$

where $\quad \mathrm{R}^{\mathrm{A}} \equiv\left(\mathrm{nP}^{\rho}+\mathrm{m}(1+\tau)^{\rho} \mathrm{Q}^{\rho}\right)^{\frac{1}{\rho}}=\mathrm{p}^{-1}\left(\mathrm{n}+\mathrm{m}(1+\tau)^{\rho} \mathrm{q}^{\rho}\right)^{\frac{1}{\rho}}$,

and

$$
\rho \equiv \frac{\beta}{\beta-1},
$$


and for the third country

$$
\mathrm{V}^{*}=\mathrm{A}\left(\mathrm{R}^{*}\right)^{-\alpha} \mathrm{I}^{*}
$$

where $\left.\quad \mathrm{R}^{*}=\mathrm{p}^{-1}(\mathrm{n}+\mathrm{mq})^{\rho}\right)^{\frac{1}{\rho}}$.

A is a constant, and $\mathrm{R}^{\mathrm{k}}$ is a price index defined over the differentiated goods. These expressions become, when differentiated logarithmically,

$$
\hat{V}^{A}=-\alpha \hat{R}^{A}-(1-\alpha) \hat{t}+\hat{I},
$$

and

$$
\hat{V}^{*}=-\alpha \hat{R}^{*},
$$

where we use that $\hat{I}^{A}=\hat{I}^{B} \equiv \hat{I}$, and that $\hat{I} *=0$.

Concentrate for a moment on the change in the price

index $R^{A}$. The relative change can be split up into two components:

$$
\hat{\mathrm{R}}^{\mathrm{A}}=\left[\frac{\mathrm{m}}{\mathrm{n}+\mathrm{m}}(\hat{\mathrm{q}}+\hat{\tau})-\hat{\mathrm{p}}\right]-\frac{1-\beta}{\beta} \hat{\mathrm{N}} .
$$

One component captures the effects of price changes on the price index, given the number of consumed varieties; this is the term in square brackets. The second term is the effect on the index of a change in the number of varieties available to the consumer, at given relative prices. This latter term is of course not present in the traditional analysis of customs unions, but will prove to be of considerable importance here.

Returning to the change in utility we get by substitution

$$
\hat{\mathrm{V}}^{\mathrm{A}}=-\left[\hat{\mathrm{t}}+\alpha \frac{\mathrm{m}}{\mathrm{n}+\mathrm{m}} \hat{\mathrm{T}}+\alpha \hat{\sigma N}\right]+\hat{\mathrm{I}}+\alpha \frac{1-\beta}{\beta} \hat{\mathrm{N}} \text {. }
$$


We can here identify three different effects of tariff changes. They include as usual effects stemming from the relative price changes and from the change in income (the first and second terms in (34), respectively). But there is now in addition a third term, capturing the utility effect of the change in the total number of differentiated goods, at given prices, that is induced by the tariff changes. By substituting (19) and (33) into (34) we arrive at

$$
\hat{\mathrm{V}}^{\mathrm{A}}=\alpha \frac{\theta^{*}}{\Delta} \Lambda \hat{\mathrm{t}}+\alpha\left(\frac{\Gamma}{\Delta} \Lambda-\frac{\mathrm{m}}{\mathrm{n}+\mathrm{m}}\right) \hat{\tau},
$$

where $\Lambda \equiv \sigma-\frac{1-\beta}{\beta}+\frac{1}{\theta^{A}+\theta^{B}}<0$.

and, for the rest of the world,

$$
\hat{\mathrm{V}}^{*}=\alpha\left(\left(\sigma-\frac{1-\beta}{\beta}\right) \frac{\theta^{*}}{\Delta}-1\right) \hat{\mathrm{t}}+\alpha\left(\sigma-\frac{1-\beta}{\beta}\right) \frac{\Gamma}{\Delta} \hat{\tau} .
$$

It is immediate from (35) and (36) that changes in the internal or external tariffs have ambiguous welfare effects for both union members and the rest of the world. The direction of change is largely determined by the sign of $\Lambda$, or its counterpart $\left(\sigma-\frac{1-\beta}{\beta}\right)$ in $(36)$. What, then, do these terms capture? We may get some intuition from noting that

$$
\begin{aligned}
& \frac{\partial R^{k}}{\partial n} \frac{n}{R^{k}}=\frac{n}{(n+m)} \frac{(1-\beta)}{\beta} \text {, and } \\
& \frac{\partial R^{k}}{\partial m} \frac{m}{R^{k}}=\frac{m}{(n+m)} \frac{(1-\beta)}{\beta} \text {. }
\end{aligned}
$$


The terms involving $(1-\beta) / \beta$ hence pick up utility effects, at constant prices, from the induced changes in the number of differentiated goods produced by the union members. Furthermore, from (14) and (15) we have that

$$
-\frac{\partial p}{\partial \mathrm{n}} \frac{\mathrm{n}}{\mathrm{p}}=-\frac{\partial \mathrm{q}}{\partial \mathrm{n}} \frac{\mathrm{n}}{\mathrm{q}}=\sigma^{\mathrm{A}} \equiv \sigma
$$

and symmetrically for $m$ and $\sigma^{B}$. The $\sigma$-terms therefore capture utility effects that come from the change in relative prices caused by shifting resources from one sector to another. Had the technology of the union members' food sectors been Ricardian, so that such shifts had left the alternative cost of the production of manufactures unchanged, these terms would have vanished $(\sigma=0)$. Whether the tariff changes improve or worsen welfare hence partly depends on the extent to which utility changes, due to changes in the consumption composition, are offset by induced changes in the relative prices of goods.

\section{Tariff Changes}

Our comparative statics experiments incorporate the two types of changes in union commercial policy that are of interest: changes $\hat{t}$ in the common external tariff on imports of food, and the marginal imposition $\hat{\tau}$ of a mutual internal tariff on the exchange of differentiated manufactured goods. Consider each in turn.

\subsection{An Increase in the Common External Tariff}

Let us first examine the implication of an increase in the already positive common external tariff $t$. From (30) and (31):

$$
\hat{\mathrm{n}}=\hat{\mathrm{m}}<0 \text {. }
$$


The number of varieties of both types of differentiated goods fall as, in each partner country, resources are pulled from manufacturing into the now more highly protected agricultural sector. The contraction of manufacturing is entirely a reduction in the number of product varieties; each produced variety experiences no change in its level of production. With a common external tariff on food, (20) implies that $\hat{q}=\sigma(\hat{m}-\hat{n})=0$, so that no substitution between product varieties is induced. ${ }^{4}$ Our assumption about the third country ensures that it continues to export $\alpha \mathrm{L}^{*}$ units of food. The shift of demand in A and $B$ away from food turns the terms of trade in favor of the union. We have $\hat{p}=-\hat{t}-\sigma \hat{n}$, and substitution of (30) into this expression reveals that the relative price $p$ of food in terms of manufactures does indeed fall, though by less than the tariff increase. The member countries hence have a terms of trade gain to set against the welfare loss from less product variety. But there is, of course, an additional source of gain: the increase in income. This source is partly reflected by the third term of $\Lambda$ in (35). The direction of change in a member country's welfare is therefore ambiguous. We see that the total effect is more likely to be positive (i) the more sensitive the terms of trade are to given changes in product variety (higher $\sigma$ ), (ii) the less the evaluation of this variety (higher $\beta$ ), and (iii) the larger the share of the rest of the world in world income (smaller $\theta^{A}+\theta^{B}$ ).

The rest of the world has to face both a detrimental terms of trade effect and a reduction of product variety, and is therefore clearly worse off. Algebraically this is immediate from (36), noting that $(\sigma \theta * / \Delta)-1<0$. 


\subsection{A Marginal Internal Barrier}

Now turn at last to the exercise treated by proposition (4) and suppose that $\hat{t}=0$ but $\hat{\tau}>0$. As a starting point, assume that the partners have equal national incomes: $\theta^{A}=\theta^{B}$. Then again the numbers of varieties produced in the two member countries decline by a common amount, so that $\hat{\mathrm{q}}=\sigma(\hat{\mathrm{m}}-\hat{\mathrm{n}})=0$.

Each partner attempts to protect manufacturing, but with resources shifting over to the agricultural sector the result is just the opposite! The reason is as follows. The tariff causes each union member to divert spending from the manufactures of its partner to its own manufactures, and the fact that $\hat{q}=0$ means that the outside country has no reason to substitute between $X$ goods and $Y$ goods. Thus from (22)-(24) we see that $\hat{y}_{A}=-\hat{\tau} /(1-\beta)<0, \hat{y}_{B}=\hat{\tau} /(1-\beta)>0$, and $\hat{y}_{*}=0$. As the partners are of equal size, these effects just cancel.

The higher price of the partner's manufactures reduces demand, so that with constant output volumes of individual firms there is downward pressure on the number of firms. This is reinforced by the fact that the proportion $(1-\alpha)$ of the tariff revenue raised in the manufacturing sector is channeled into the agricultural sector. Thus the net effect is to protect food, not manufacturing. From (22)-(26) we have that $\hat{y}_{A}-\hat{z}_{A}<0$ and $\hat{y}_{B}-\hat{z}_{B}>0$, that is, a "reversal" of trade modification.

It is instructive to compare section 3 and $4^{\prime} \mathrm{s}$ discussion of proposition (4) with behavior in the altered context of the present model. First, recall that in the earlier context gains actually resulted when the reversal of trade modification caused the union to import more from the rest of the world. The structure of the 
present model allows us to concentrate on what is new by ensuring that such gains shrink to zero: our assumptions about the third country imp1y that it exportes an unchanged quantity of food to the union. Exclusively external trade is neither a substitute for nor complement to internal trade, to use our earlier terminology, and there is also now no trade diversion to "undo". Second, the terms of external trade were assumed fixed in proposition (4), but now the shift of demand toward food turns the terms of trade in the outside wrld's favor. From (15), $\hat{P}=-\sigma \hat{n}>0$. This could of course be neutralized by an appropriate increase $\hat{t}$ in the common external tariff. But the most significant difference follows from the role of imperfect competition, scale economies, and the endogenous number of product varieties. As in the conventional analysis, zero first-order walfare effects are caused by shifts in union expenditure between existing $\mathrm{X}$ goods and $\mathrm{Y}$ goods. But in our model the output levels of all product varieties which continue to be produced are unchanged, and instead the number of varieties of manufartures falls. This is deleterious. The total effect on the welfare of country $A$ or $B$ is ambiguous, as can be seen from (35). There is now one additional term, compared to the case with the external tariff, which influences the direction of change in welfare: the relative sizes of the manufacturing sectors. The larger the partner's share of total manufacturing output, the larger the share that will be hit by the tariff, and the more likely it is that the internal tariff will actually reduce welfare, and that a "super-union" will be optimal.

The external country is atfected in an ambiguous way. Its terms of trade improve, so that it consumes more manufactures 
than before along with the same quantity of food. But, on the other hand, those manufactures possess less product diversity than before. In summary, it is possible that all countries lose from the internal tariff, or that all gain, with $\theta^{A}=\theta^{B}$. It is also possible that the member countries gain and the rest of the world loses. But, if the member countries lose, then so must the external country, rendering a "super-union" beneficial to all!

Thus far we have supnosed that $\theta^{A}=\theta^{B}$. The role of size disparities between partners is now easily exposed. (30)-(33) show that the internal tariff will still cause a decline in total output of manufactures, but that the smaller country will have to adjust its manufacturing sector more than proportionally: $\hat{\mathrm{n}}>\hat{\mathrm{m}}<0$. There is hence a reallocation of manufacturing from the smaller (in terms of national income) partner to the larger. Intuitively, small-country located firms will have a larger share of production hit by the tariff, inducing more exit to keep profits at zero. Indeed, it might possibly be the case that the larger partner's manufacturing output actually rises, if the difference in national incomes is sufficiently large. This reallocation of production might be one reason why customs unions tend to be formed by similar economies.

\subsection{Intermediate goods}

There is an alternative interpretation of our model. Assume only two consumption goods, food and a final manufacture, but many differentiated intermediate goods, or components, used to assemble the final manufacture. This interpretation is entirely consistent 
with our formulation if we let the CES part of the utility function (10) be the assembly function for the final manufacture, $x_{i}^{k}$ and $\mathrm{Y}_{j}^{\mathrm{k}}$ represent the inputs of components $\mathrm{i}$ and $j$, and the parameter $\beta$ reflect the degree of substitutability between different components. The technology is then such that each single producer of an intermediate good faces internal increasing returns to scale available when the production process is geographically concentrated: an example of "national" economies of scale. ${ }^{5}$ Assembly of the final manufacture is costless, and exhibits increasing returns to scale in the number of different components that are used. To see this, note that the CES assembly function gives an output of $n^{\frac{1}{\beta}}$ in the symmetric version, and hence the output increases faster than the input $\mathrm{nX}$. These economies of scale are "international", since the size of the world market for the manufacture determines $n$, and they also reflect the benefits of an increased division of labor in the world economy; they are assumed to be external to individual assembly firms.

There is, in this interpretation, trade both in intermediate goods, and in the final good food. There is initially a tariff only on the latter good, which is exported by the external country. It is immaterial whether finished manufactures are assembled where consumed, or whether they are all assembled in one partner country and then exported. But in the latter case the interesting possibility of tariffs on final manufactures is not covered by our analysis, the components must be taxed the same whether imported directly or embodied in final manufactures, and exports of the latter must be allowed drawbacks of tariffs paid for imported components. The total impact 
on each country's welfare of tariff changes is, of course, the same irrespective of model interpretation. What differ are the sources of welfare changes. We saw above that an increase in either the internal or external tariff reduced both $\mathrm{n}$ and $\mathrm{m}$ unless the partners were too different in terms of their national incomes. Here this means that fewer components will be used in the production of manufactures, leading to a situation with less exploitation of international returns to scale. The main welfare-reducing effect of the tariffs is thus that they are detrimental to the division of labor by diminishing the world market for the final manufacture. But, there is no loss here stemming from reduced exploitation of the traditional, national returns to scale. The two developed countries are trying to protect their home industries, and manage in the sense that a higher proportion of inputs are locally made. But with both countries acting in a similar fashion no over-all gain is ensured.

\section{Concluding Remarks}

We live in a multilateral world. Therefore any nonuniversal change in commercial policy -- and they are all in fact non-universal -- ought to fall within the domain of the theory of economic intergration. But it has not been so, since that theory usually has been too narrowly conceived. We have argued for four extensions: trade modification, consideration of small changes in policy, scale economies, and product differentiation/imperfect competition.

Adding the first two of these suggested extensions to the conventional framework we derived two basic propositions, suggested by familiar second-best theory, that are central to the characterization of the optimal policy for a subset of countries considering some degree of integration in a tariff-ridden world. We 
then developed a special, but illustrative, model incorporating al1 four of our suggested extensions and put it through its paces. Such an exercise is no more than an uncertain first step. But it is in the direction that must be followed, we maintain, if the theory of economic integration is to achieve the relevance to contemporary issues that it long since ought to have possessed. 
$1 \quad B$ exports only to $A$

2 B exports to $A$ and to the rest of the world

3 the rest of the world exports only to $A$

4 the rest of the world exports to $A$ and to $B$

5 the rest of the world and B both export to $A$

6 A exports only to B

7 the rest of the world and A both export to $B$

8 A exports only to the rest of the world

9 A and B both export to the rest of the world

10 A exports to both $B$ and the rest of the world

11 B exports only to the rest of the world

12 the rest of the world exports only to $B$

Table 1. Description of the commodity groups 


\section{Footnotes}

* Henrik Horn gratefully acknowledges financial support from Humanistisk-Samhällsvetenskapliga Forskningsrådet, Sweden.

1. See Meade $(1955,1956)$ and Ethier (1983, chapter 12)

2. The most notable exception is no doubt James Meade (1955, 1956), who was criticised in this regard. For example Lipsey (1967, p. 271) refers to this "very serious, possibly crippling, limitation". The subsequent literature has largely avoided marginal analysis.

3. For such a discussion, see section of Appendix I in Ethier (1983).

4. In the more general case $\sigma^{A} \neq \sigma^{B}$ we would have $\sigma^{A} \hat{n}=\sigma \hat{m}$ so that manufacturing contracts relatively more in the country with the greater ease of substitution of food for the nontraded manufacturing intermediate good; the structure of such economies remains-irretevant. Also we would still have $0=q^{\prime}=\sigma B \hat{m}-\sigma A \hat{n}$.

5. See Ethier (1979, 1982). 


\section{$\underline{\text { References }}$}

Dixit, A.K. and J. Stiglitz, 1977, Monopolistic competition and optimum product diversity, American Economic Review 67.

Ethier, W., 1979, Internationally decreasing costs and world trade, Journal of International Economics 9.

Ethier, W.J., 1982, National and international returns to scale in the modern theory of international trade, American Economic Review 72.

Ethier, W.J., 1983, Modern International Economirs (W.W. Norton, New York).

Kemp, M.C., 1964, The Pure Theory of International Trade (PrenticeHa11, Englewood Cliffs).

Kemp, M.C. and H.Y. Wan, 1975, An elementary proposition concerning the formation of customs unions, Journal of International Economics 5.

Kravis, I.B. and R.E. Lipsey, 1971, Price competitiveness in world trade (National Bureau of Economic Research, New York).

Kravis,I.B. and R.E. Lipsey, 1978, Price behavior in the light of balance of payments theories, Journal of International Economics 8.

Lipsey, R.E., 1968, The theory of customs unions: A general survey, in R.E. Caves and H.G.Johnson (eds.), Readings in International Economics (Richard D. Irwin, Homewood).

Meade, J.E., 1955, Trade and welfare (Oxford University Press, London).

Meade, J.E., 1956, The Theory of Customs Unions (North Holland, Amsterdam.

Ohyama, M., 1972, Trade and Welfare in General Equilibrium, Keio Economic Studies 9. 
Vanek, J., 1965, General Equilibrium of International Discrimination (Harward University Press, Cambridge).

Viner, J., 1950, The Customs Union Issue (Carnegie Endowment for International Press, New York). 

The series was initiated in 1971. For a complete list of Seminar Papers see the Institute's annual brochure.

116. Carl Homizton:

117. Thorvaldur Gylfason:

118. Michael Brmo and Jeffrey Sachs:

119. Harvey Lapan and Roy Gardner:

120. Gary P. Sampson and Richara H. Snope:

121. Lance Tayzor:

122. Torsten Persson:

123. John F. HezziweZz:

124. Mordechai E. Kreinin:

125. Mordechai E. Kreinin:

126. Ronald W. Jones

127. Lars Calmfors and Staffan Viotti:

128. Kalyan K. Sanyal and Ronald $W$. Jones:

129. EZhanan HeZpman:

130. Clas G. Wihlborg and Per M. Wijkman:
Import Penetration and Import Price Elasticities with Special Reference to Dynamic LDC Export

Commodities: The Case of Sweden 1960-75. 36 pp.

Interest, Inflation and the Aggregate Consumption Function. 44 pp.

Macro-Economic Adjustment with Import Price Shocks:

Real and Monetary Aspects. 51 pp. *

The von Neumann Iurnpike under Uncertainty:

2-Sector Case. 24 pp.

Effects of Variable Import Levies and Options for Retaliation. $26 \mathrm{pp}$.

Denationalization vs. National Growth: Who Gains from the "Advantage" of the MNC's? $19 \mathrm{pp}$.*

Alternative Iransactions Variables in Money Demand Equations: A lote on the Baumol-Tobin Theory. 15 pp.

Policy Modelling of Foreign Exchange Rates. 33 pp. (Also as Reprint No. 131)

United States Foreign Economic Policy - An Overview. 34 pp. (Also as Reprint No. 137)

Effect of European Integration on Trade Flows in Manufactures. $28 \mathrm{pp}$.

Demand Behavior and the Theory of International Trade. $34 \mathrm{pp}$. (Also as Reprint lio. 151)

Wage Indexation and Macroeconomic Stability in the Open.Economy $32 \mathrm{pp} *$ *

The Theory of Trade in Middle Products. $65 \mathrm{pp}$. (Also as Reprint No. 183)

Inflation and Balance of Payments Adjustments with Maximizing Consumers. 34 pp.

Outer Space Resources in Efficient and Equitable Use - New Frontiers for Old Principles. 30 pp. (Also as Reprint No. 165) 
131. Laurence Weiss:

132. J.A. Frenkel, T. Gylfason and J.F. Helziwelz:

133. Thorvaldur Gylfason ana Assar Lindbeck:

134. P.K.M. Tharakan:

135. Pavel Pelikan:

1980

136. Stanzey W. Black:

137. Gordon C. Winston:

138. Per M. Wijkman:

139. Pekka Ahtiala and Jean M. Blin:

140. Carl Van Duyne:

141. Torsten Persson:

142. Clas Wihlborg:

143. J. Peter Neary:

144. Peter J. LZoyd:

145. Peter J. LZoyd:

146. Peter J. LZoyd:

147. Ake G. Elomqvist:

148. Assar Lindbeck:

149. Richard T. Sezden:
Information Aggregation and Policy. $26 \mathrm{pp}$.

A Synthesis of Monetary and Keynesian Approaches to Short-Run Balance-of-Payments Theory. 20 pp. (Also as Reprint No. 141)

Cost Inflation and Macroeconomic Theory. 66 pp.

Political Economy of Protection - An Empirical

Investigation of the Belgian Case. $30 \mathrm{pp}$.

Towards a Rational Method of Choosing Economic Institutions. $60 \mathrm{pp}$.

Central Bank Intervention and the Stability of Exchange Rates. 26 pp.

The Timing of Work and Consumption, I: A TimeSpecific Household Production Mode1. 50 pp.

Effects of Cargo Reservation: A Review of UNCTAD's Code of Conduct for Liner Conferences. 63 pp.

Inflation Risk, Resource Allocation and the Social Cost of Inflation. $18 \mathrm{pp}$.

Food Prices, Expectations, and Inflation. 39 pp.

Currency Areas and Alternative Exchange Rate

Regimes in a Simple Tinree-Country General

Equilibrium Model. 36 pp.

Commodity and Labor Market Rigidities in a Monetarist Model of Exchange Rate Determination. $37 \mathrm{pp}$.

Intersectoral Capital Mobility, Wage Stickiness and the Case for Adjustment Assistance. $36 \mathrm{pp}$.

$3 \times 3$ Theory of Customs Unions. $41 \mathrm{pp}$.

Economies of Scale Due to the Length of Iroduction Runs. $34 \mathrm{pp}$.

The Effects of Trade Interventions on Internaticnal Price Instability and National Welfare. $34 \mathrm{pp}$.

International Migration of Educated Manpower anci Social Rates of Return to Education in LDCs. $41 \mathrm{pp}$.

Tax Effects versus Budget Effects on Labor Supply. $41 \mathrm{pp}$.

The Inflationary Seventies: Comparisons among Selected High-Income Countries. 27 pp. 
150. Lars E.O. Svensson:

151. Ronald W. Jones:

152. Carl Hamizton and Lars E.O. Svensson:

153. Jomes R. Markusen:

154. James R. Markusen and Jomes R. MeZvin:

155. EZhanan HeIpman and Assaf Razin:

156. Elhanan HeZpman and Assaf Razin:

157. Eihanan HeZpman:

158. J. Peter Neary:

159. Assaf Razin:

160. Jomes R. Markusen:

161. Dennis Warner and Mordechai E. Kreinin:

163. Michael Michaely:

164. Assar Lindbeck:

165. Roy J. Ruffin:
162. Michael Michaely:

National. Welfare in the Presence of Foreign-Owned Factors of Production: A Note cn the Dual Approach. $19 \mathrm{pp}$.

Comparative and Absolute Advantage. 45 pp. (Also as Reprint No. 153)

On Welfare Effects of a "Duty-Free Zone". 39 pp.

Trade and the Gains from Trade with Imperfect Competition. 28 pp.

Trade, Factor Prices, and the Gains from Trade with Increasing Returns to Scale. $35 \mathrm{pp}$.

Monopolistic Competition and Factor Movements. $23 \mathrm{pp}$.

A Comparison of Exchange Rate Regimes in the Presence of Imperfect Capital Markets. 42 pp. International Trade in the Presence of Product Differentiation, Economies of Scale, and Monopolistic Competition: A Chamberlin-HeckscherOhlin Approach. 58 pp. (Also as Reprint No..968)

International Factor Mobility, Minimum Wage Rates and Factor-Price Equalization:

A Synthesis. 32 PP.

Capital Movements, Intersectoral Resource Shifts, and the Trade Balance. $33 \mathrm{pp}$.

Multinationals and the Gains from Trade:

A Theoretical Analysis Based on Economies of Multi-Plant Operation. $40 \mathrm{pp}$.

Determinants of International Trade Flows. 31 pp.

The Terms of Trade between Poor and Rich Nations. $36 \mathrm{pp}$.

Capital Imports, Economic Structure, and Dependence. $32 \mathrm{pp}$.

Work Disincentives in the Welfare state. $60 \mathrm{pP}$. (Also as Reprint No. 176)

Taxing International Capital Movements in a Growing World. $38 \mathrm{pp}$.

The Neutrality of Money and the Analysis of Alternative Exchange Rate Regimes. 28 pp.

167. Roy J. Ruffin:
Trade and Factor sovements with Three Factors and Two Goods. 19 pp. (Also as Reprint No. 170) 
168. Carl Homizton:

169. Marian Radetzki:

170. Lars. E. O. Svensson and Assaf Razin:

171. Assar Lindbeck:

172. Ake G. Blomqvist:

173. Per Magnus Wijkman:

174. CarZ Hamizton:

175. Lars Calmfors:

176. Carl Van Duyne:

177. Peter Svedberg:

178. Carr Hamizton and Lars E.O. Svensson:

179. Henrik Horn:

180. Thorvaldur Gylfason and John F. HeZliwe ZI:

181. EZhanan HeZpman and Assaf Razin:

182. Mario I. Blejer and Hans Genberg:

183. Torsten Persson:
A New Approach to Estimation of the Effects of Non-Tariff Barriers to Trade on Prices, Employment and Imports: An Application to the Swedish Textile and Clothing Industry. 65 pp. (Also as Reprint No. 160)

Has Political Risk Scared Minerals Investments away from the Deposits in Developing Countries? 24 pp. (A1so as Reprint No. 174)

The Terms of Trade, Spending, and the Current Account: The Harberger-Laursen-Metzler Effect. $43 \mathrm{Fp}$.

The Distribution of Factor Income versus Disposable Income in a Welfare State: The Case of Sweden. $84 \mathrm{pp}$.

Education, Unemployment and Government Job Creation for Graduates in LDCs. 35 pp.

Seigniorage, Financial Intermediation, and the International Role of the Dollar, 1960-1971. $48 \mathrm{pp}$.

Public Subsidies to Industry: The Case of Sweden and Its Shipbuilding Industry. $31 \mathrm{pp}$.

Output, Inflation and the Terms of Trade in a Small Open Economy. 25 pp.

Price Determination in Markets for Storable Commodities. $30 \mathrm{pp}$.

Colonialism and Foreign Direct Investment Profitability. $35 \mathrm{pp}$.

On the Choice Between Capital Import and Labor Export. 47 pp.

Some Inplications of Non-homotheticity in Production in a Two-sector General Equilibrium Model with Monopolistic Competition. 39 pp.

A Synthesis of Keynesian, Monetary, and Portfolio Approaches to Flexible Exchange Rates. $37 \mathrm{pp}$.

The Role of Saving and Investment in Exchange Rate Determination under Alternative Monetary Mechanisms. $33 \mathrm{pp}$.

Permanent and Transitory Shocks to Exchange Rates: Measurement and Implications for Purchasing Power Parity. 36 pp.

Global Effects of National Stabilization Policies under Fixed and Floating Exchange Rates. 45 Pp. 
184. Lars E.O. Svensson:

185. Michael Hoel:

186. Martin Feldstein:

187. Jeffrey Sachs:

188. J. Peter Neary and Douglas D. Purvis:

189. Tomas Björk, Johan Myhrman, and Mats Persson:

190. John $\vec{F}$. Helziwezl, Paul M. Boothe, and Robert N. MeRae:

191. Nancy P. Marion and Lars E.O. Svensson:

192. Lars Calmfors:

1982

193. Michael Brino:

194. Assaf Razin and Lars E.O. Svensson:

195. W.M. Corden and J.P. Neary:

196. Torsten Persson and Lars E.O. Svensson:

197. Lars E.O. Svensson:

198. Wilfred J. Ethier:

199. Harry Flam, Torsten Persson, and Lars E.O. Svensson:

200. Lars E.O. Svensson:

201. Thorvaldur Gylfason and Michael Sehmid:
Oil Prices and a Small Oil-Importing Economy's Welfare and Trade Balance: An intertemporal approach. 55 pp.

Short Run and Long Run Effects of a Tax Cut in an Open Economy with a Sticky Real Wage. $60 \mathrm{pl}$.

Inflation, Tax Rules and the Accumulation of Residential and Nonresidential Capital. 32 pp.

The Current Account in the Macroeconomic Adjustment Process. 20 pp.

Sectoral Shocks in a Dependent Economy:

Long-Run Adjustment and Short-Run Accommodation. $58 \mathrm{pp}$.

Consumption and Savings under Price Uncertainty. $40 \mathrm{pp}$.

Stabilization, Allocation and the 1970s 0il Price Shocks. 53 pp.

World Equilibrium with Oil Price Increases: An Intertemporal Analysis. $38 \mathrm{pp}$.

Employment Policies, Wage Formation and Trade Union Behavior in a Small Open Economy. $39 \mathrm{pp}$.

Adjustment and Structural Change Under Supply Shocks. 39 pp.

The Current Account and the Optimal Government Debt. $21 \mathrm{pp}$.

Booming Sector and De-Industrialisation in a Small Open Economy. 45 pp.

Is Optimism Good in a Keynesian Economy? $19 \mathrm{pp}$.

On Variable Capital Utilization and International Trade Theory. $14 \mathrm{pp}$.

International Trade and Labor Migration. 30 pp.

Optimal Subsidies to Declining Industries:

Efficiency and Equity Considerations. $28 \mathrm{pp}$.

Factor Trade and Goods Trade. 37 pp.

Do Devaluations Cause Stagflation? 27 pp. 
202. Lars Hömgren, Johan Myhrman, Per-Ake Nilsson, Staffan Viotti and Anders Vredin:

203. Hans Tson Söderström and Eva Udán-Jondal:

204. Jonathan Eaton and Henryk Kierzkowski:

205. Pehr Wissén:

206. Carl Homilton and Lars E.O. Svensson:

207. John T. Cuddington:

208. Carl Hamilion and Lars E.O. Svensson:

209. Carl Hamizton and Lars E.O. Suensson:

210. Avinasin Dixit:

211. M June Flanders:

212. Ronald $N$. Jones and Douglas D. Zumis:

213. Ake Blomquist and Henrik Horn:

214. Carl Hamition:

215. Thorvaldur Gyljason:

216. John T. Cudaington:

217. Michael Schmid:

218. Wilfred J. Ethier:

219. Paul R. Kmugman, Torsten Persson and Lars E.O. Svensson:
The SSEM Mode1 - A Brief Description. 24 pp.

Does Egalitarian Wage Policy Cause Wage Drift? An Empirical Study of Sweden 1960-1979. 49 pp.

Oligopolistic Competition, Product Variety and International Trade. $36 \mathrm{pp}$.

Growth Models for Open Economies with NonShiftable, Malleable Capital and Nontraded Goods. 63 pp.

Should Direct or Total Factor Intensities be Used in Tests of the Factor Proportions Hypothesis in International Trade Theory? 22 pp.

Portfolio Balance and IS-LM: A Marriage under Fixed Exchange Rates. 40 pp.

Revealed Comparative Advantage: The Case of Sweden. 20 pp.

Testing Theories of Trade among Many Countries. $62 \mathrm{pp}$.

Growth and Terms of Trade under Imperfect Competition. 25 pp.

The Balance-of-Payments Adjustment Mechanism:

The Doctrine According to Ohlin. 31 pp.

International Differences in Response to Common External Shocks: The Role of Purchasing Power Parity. $38 \mathrm{pp}$.

Public Health Insurance and Optimal Income Taxation. 32 pp.

Agricultural Protection in Sweden 1970-1980. 25 pp.

Why Rational Expectations do not Neutralize Monetary Policy. 8 pp.

Currency Substitution, Capital Mobility and Money Demand. $25 \mathrm{pp}$.

International Adjustment to an 0il Price Shock - The Role of Competitiveness. 49 pp.

Higher Dimensional Issues in Trade Theory. $96 \mathrm{pp}$.

Inflation, Monetary Velocity and Welfare. $27 \mathrm{pp}$. 
220. Lars E.O. Svensson:

221. Wilfred Ethier and Henrik Horm:
An Asymmetry Between Import and Export Taxex. $11 \mathrm{pp}$.

A New Look at Economic Integration. 39 pp. 
